\section{ESTÉTICA de la}

\section{INTERACCIŌN}

DENTRO y MĀS

\section{ALLĀ del FLUIR}

INTERACTION

AESTHETICS In

and BEYOND

the FLOW

\begin{tabular}{l} 
DISEÑA 15 - AGOSTO 2019 \\
\hline ISSN: $0718-8447$ (impreso); $2452-4298$ (electrónico) \\
\hline COPYRIGHT: CC BY-SA 3.0 CL \\
Artículo de investigación original \\
Recepción 21 de febrero 2019 \\
\hline Revisión 29 de mayo 2019 \\
Aceptación 31 de mayo 2019 \\
\hline Cómo citar este artículo: \\
NÚÑEZ PACHECO, C. (2019). Estética de la interacción dentro y más \\
allá del fluir. Diseña, (15), 48-69. Doi: 10.7764 /disena.15.48-69 \\
\hline Traducción: José Miguel Neira \\
\hline
\end{tabular}

CLAUDIA NÚÑEZ PACHECO

UNIVERSIDAD AUSTRAL DE CHILE

ESCUELA DE DISEÑO

VALDIVIA, CHILE

claudia.nunez@uach.cl

\begin{tabular}{l} 
DISEÑA 15 - AUGUST 2019 \\
ISSN: $0718-8447$ (print); 2452-4298 (electronic) \\
\hline COPYRICHT: CC BY-SA 3-0 CL \\
Original Research Article \\
Reception February 21, 2019 \\
Revision May 29, 2019 \\
Acceptance May 31, 2019 \\
How to cite this article: \\
NÚÑEZ PACH ECO, C. (2019). Interaction Aesthetics In and Beyond \\
the Flow. Diseña, (15), 48-69. Doi: 10.7764/disena.15.48-69 \\
\hline
\end{tabular}

CLAUDIA NÚÑEZ PACHECO

UNIVERSIDAD AUSTRAL DE CHILE

SCHOOL OF DESIGN

VALDIVIA, CHILE

claudia.nunez@uach.cl 
Claudia Núñez Pacheco Diseñadora, Universidad de Valparaíso. Master en Diseño de Interacción y Artes Electrónicas, University of Sydney. PhD en Diseño de Interacción, University of Sydney. Profesora Asistente en la Escuela de Diseño de la Universidad Austral de Chile. Sus intereses de investigación incluyen la Interacción Humano-Computador (HCI), el diseño somaestético, la estética de la interacción, la investigación en diseño, los métodos de diseño, el diseño sensorial y el design thinking. Es coautora de Design. Think. Make. Break. Repeat. A Handbook of Methods (con M. Tomitsch, C. Wrigley, M. Borthwick, N. Ahmadpour, J. Frawley, B. Kocaballi, K. Straker y L. Loke; BIS Publishers, 2018). Algunos de sus artículos más recientes son "Towards a Technique for Articulating Aesthetic Experiences in Design using Focusing and the Felt Sense" (con L. Loke; The Design Journal, vol. 21, $\mathrm{n}^{\circ} 4$ ) y "Reflection through Inner Presence: A Sensitising Concept for Design" (Multimodal Technologies and Interaction, vol. 2, $\mathrm{n}^{\circ} \mathrm{1}$ ).
Claudia Núñez Pacheco Designer, Universidad de Valparaíso. Master of Interaction Design and Electronic Arts, University of Sydney. PhD in Interaction Design, University of Sydney. She is Assistant Professor in the School of Design at Universidad Austral de Chile. Her research interests include Human-Computer Interaction ( $\mathrm{HCl}$ ), Somaesthetic Design, Aesthetics of Interaction, Design Research, Design Methods, Sensory Design, and Design Thinking. She is co-author of Design. Think. Make. Break. Repeat. A Handbook of Methods (with M.

Tomitsch, C. Wrigley, M. Borthwick, N. Ahmadpour, J. Frawley, B. Kocaballi, K. Straker, and L. Loke; BIS Publishers, 2018). Some of her most recent articles are 'Towards a Technique for Articulating Aesthetic Experiences in Design using Focusing and the Felt Sense' (with L. Loke; The Design Journal, Vol. 21, $\mathrm{N}^{\circ} 4$ ) and 'Reflection through Inner Presence: A Sensitising Concept for Design' (Multimodal Technologies and Interaction, Vol. 2, $\mathrm{N}^{\circ} 1$ ). 
Casi dos décadas después de que el término estética de la interacción hiciera su aparición en el campo del diseño orientado a la Interacción Humano-Computador ( $\mathrm{HCI}$ ), el entendimiento del concepto permanece nebuloso y centrado en la descripción de aquellas cualidades específicas que podrían llegar a generar una experiencia estética. Sin embargo, al tratar de describir las interacciones estéticas desde la perspectiva de sus cualidades, nos arriesgamos a ofrecer un sinfín de definiciones, en la mayoría de los casos enfrascándonos en potenciales rasgos positivos. De esta forma, podríamos llegar a ignorar otras expresiones de interacción conducentes a experiencias de significados igualmente profundos. Basándonos en las similitudes existentes entre lo que John Dewey entiende por experiencia estética, la definición de "modelo procesal" de Eugene Gendlin y el análisis del concepto de equipamiento de Martin Heidegger, este artículo ofrece un marco teórico que contribuye con una visión sistematizada y amplia de lo que representa la estética de la interacción. Para esto, la discusión ejemplifica distintos rangos de experiencias fenomenológicas, incluyendo la transparencia y el quiebre como dos polos opuestos en el entendimiento de la manera en que las tecnologías se revelan a sí mismas.
Although almost two decades have passed since the term aesthetics of interaction made its appearance in design-oriented Human-Computer Interaction ( $\mathrm{HCl}$ ), the actual understanding of the concept remains fuzzy and focused on the description of qualities of what constitutes an aesthetic experience. However, by trying to describe specific aesthetic qualities emerging from technology encounters, we risk offering endless definitions of potential aesthetic traits, mostly fixated on pleasurable interactions. This approach may discard other interactive expressions that could potentially lead us to meaningful insights. Drawing on the similarities

Human-Computer Interaction Implying-Occurring between John Dewey's aesthetic experiences, Eugene Gendlin's process model, and Martin Heidegger's analysis of tool use, this article offers a theoretical framework towards a broader, systematized view of aesthetics of interaction. To do so, the discussion exemplifies a series of phenomenological experiences ranging from transparency to breakdown: two opposites in the understanding of how technologies reveal themselves. 
HACIA UNA PERSPECTIVA HUMANISTA SOBRE LA ESTÉTICA DE LA INTERACCIÓN

El término estética de la interacción encapsula una serie de interpretaciones y aproximaciones, particularmente en términos de las cualidades asociadas con aquello que hace que una experiencia interactiva sea significativa. En el campo del diseño, el concepto de estética se ha interpretado principalmente como una cuestión de atractivo visual (algunos ejemplos recientes incluyen los trabajos de Bader \& Lowenthal, 2018; o Pappas, Sharma, Mikalef, \& Giannakos, 2018), aunque en el ámbito de la Interacción Humano-Computador (HCI) orientada al diseño la estética se asocia principalmente con nociones positivistas de la experiencia (Folkmann, 2018). Estas nociones incluyen perspectivas orientadas hacia la psicología que tienden a analizar y medir experiencias estéticas según las necesidades, los rasgos psicológicos y las cualidades experienciales de la interacción (Hassenzahl, 2010; Hassenzahl, Diefenbach, \& Göritz, 2010; Hekkert, 2006 ; Lenz, Hassenzahl, \& Diefenbach, 2017; Sutcliffe, 2009). Desde una perspectiva más humanista, las experiencias estéticas son interpretadas como instancias performativas que se enfocan en brindar significado como un valor holístico de la interacción (McCarthy y Wright, 2004). Parece no existir un consenso real con respecto a las condiciones que allanan el camino para las experiencias estéticas en el contexto de la interacción, aunque varios investigadores se han referido, como punto de partida para el desarrollo de sus marcos conceptuales, al planteamiento de John Dewey de lo que significa vivir una experiencia (ver: Dewey, 1934).

Alineado con una visión humanista inspirada en el pragmatismo de Dewey, este artículo busca proponer una visión sistemática de las experiencias estéticas en el contexto de la interacción con objetos, alejándose de la tendencia que procura describir cualidades específicas de la interacción. La importancia de ofrecer alternativas al uso de cualidades reside en que el diseño es una actividad situada (Kimbell, 2011), lo que significa que las definiciones específicas podrían no siempre alinearse con la naturaleza contextual de las interac-
TOWARDS A HUMANISTIC PERSPECTIVE ON AESTHETICS OF INTERACTION

The term aesthetics of interaction encapsulates a series of interpretations and approaches, particularly in terms of qualities associated with what makes an interactive experience meaningful. In design, the concept of aesthetics has been primarily interpreted as a matter of visual appeal (see some recent examples such as Bader \& Lowenthal, 2018; or Pappas, Sharma, Mikalef, \& Giannakos, 2018), although in design-oriented $\mathrm{HCl}$, aesthetics is mostly associated with positivist notions of experience (Folkmann, 2018). These notions include psychological oriented perspectives, which tend to analyze and measure aesthetic experiences regarding psychological needs, traits, and experiential qualities of interaction (Hassenzahl, 2010; Hassenzahl, Diefenbach, \& Göritz, 2010; Hekkert, 2006; Lenz, Hassenzahl, \& Diefenbach, 2017; Sutcliffe, 2009). From a more humanistic perspective, aesthetic experiences are seen as performative instances, focusing on delivering meaningfulness as a holistic value of interaction (McCarthy \& Wright, 2004). It seems that there is no actual consensus regarding the preconditions paving the way for aesthetic experiences in the context of interaction, albeit several researchers have referred to John Dewey's understanding of what it means to have an experience as a starting point for the development of their frameworks (see: Dewey, 1934).

Aligned with a humanistic view inspired by Deweyan pragmatism, this paper aims to propose a systematic view of aesthetic experiences in the context of interaction with objects, distancing itself however from the tendency to describe specific qualities of interaction. The relevance of offering alternatives to qualities resides in the fact that design is a situated activity (Kimbell, 2011), meaning that specific definitions might not always be aligned with the contextual nature of desired interactions. To do so, it returns to the Deweyan description of having an experience, focusing on the 
ciones deseadas. Para cumplir su propósito, el texto retoma la descripción de Dewey de lo que es tener una experiencia, centrándose en la estructura de la construcción de significado como material fundamental (Dewey, 1934). Para contribuir al análisis de manera más detallada, el artículo presenta el "modelo procesal" de Gendlin (2012), quien, al igual que Dewey, pone énfasis en la naturaleza generativa y continua de las experiencias cotidianas. Este artículo también alude brevemente al análisis de Heidegger sobre el papel de las herramientas en nuestro ser-en-el-mundo para discutir la transparencia y la aparición de la tecnología en nuestra consciencia. Finalmente, y moldeado por los conceptos que emergen de estas tres teorías, se ofrece un marco sobre las experiencias estéticas con artefactos interactivos que toman en consideración las nociones encarnadas de "transparencia" y "quiebre" como puntos de partida para introducir la reflexión en la ecuación. Este marco tiene como objetivo describir diferentes casos o modalidades en que ocurren experiencias estéticas, atendiendo a una variedad de relaciones encarnadas con la tecnología. Algunos ejemplos incluyen la interacción con tecnologías que implican estos escenarios encarnados: (1) la transparencia del artefacto, (2) un diálogo con el artefacto, (3) el diseño de obstáculos para el fluir y (4) el quiebre. La razón por la cual el marco propuesto utiliza el concepto de transparencia como punto de partida para el análisis es que, históricamente, se le ha considerado como una meta para los sistemas interactivos (Weiser, 1991). Además, para Dewey (1934), y de manera similar para Gendlin (1992), tener una experiencia estética requiere un reconocimiento reflexivo de que tal evento es emocionalmente significativo. Esta premisa desafía la visión predominante de que «las tecnologías más profundas son las que desaparecen» (Weiser, 1991, p. 19), ya que la transparencia podría no siempre permitir encuentros estéticos.

\section{DEWEY Y LAS EXPERIENCIAS ESTÉTICAS}

Las experiencias estéticas son excepcionales para quienes las experimentan; sin embargo, esta cualidad particular nunca se separa de lo cotidiano. Para structure of experiencing meaning as foundational material (Dewey, 1934). To further contribute to the analysis, it introduces Gendlin's process model (2012), which like Dewey, places its emphasis on the generative and ongoing nature of quotidian experiences. Briefly, this article also alludes to Heidegger's analysis of the role of tools in our being-in-the-world, to discuss transparency and appearance of technology in our consciousness. Finally, shaped by the concepts emerging from the three theories, it offers a framework on aesthetic experiences with interactive artifacts taking into consideration the embodied notions of 'transparency' and 'breakdown' as starting points to introduce reflection into the equation. This framework aims to describe different cases or modalities when aesthetic experiences occur, attending to a variety of embodied relations with technology. Such examples include the interaction with technologies that include these embodied scenarios: (1) Transparency of equipment, (2) a dialogue with equipment, (3) the design of obstacles to the flow, and finally, (4) the breakdown. The reason why the proposed framework uses the concept of transparency as a starting point for its analysis is that historically, it has been considered as a goal for interactive systems (Weiser, 1991). Additionally, for Dewey (1934) - and similarly for Gendlin (1992) - having an aesthetic experience requires a reflective acknowledgment that such an event is emotionally meaningful. This premise defies the prevalent view, that is, that "the most profound technologies are those that disappear" (Weiser, 1991, p. 19), as transparency might not always enable aesthetic encounters.

\section{DEWEY AND AESTHETIC EXPERIENCES}

Aesthetic experiences are remarkable for those who experience such instances, yet this particular quality is never detached from everydayness. For Dewey (1934), aesthetic experiences were not necessarily relegated to art museums for appreciation by the elites, albeit were part of everyday patterns 
Dewey (1934) las experiencias estéticas no necesariamente estaban relegadas a las galerías de arte frecuentadas por las élites, sino que formaban parte de los patrones cotidianos de la vida. La trascendencia de tales experiencias estaba determinada por la relación entre la criatura viviente y las condiciones que ofrece su entorno. Dewey afirma que las experiencias estéticas fluyen de un punto determinado a otro y que exhiben un movimiento organizado. Una experiencia estética (o tener una experiencia, según él) encarna una unidad de eventos que brinda una sensación de satisfacción, donde quien está experimentando el flujo espera su desenlace, al tiempo que también se enfoca en el proceso en sí mismo, incluyendo una serie de eventos que se desarrollan durante el fluir (Dewey, 1934). En otras palabras, las experiencias estéticas muestran sucesiones rítmicas de movimiento, incluidos el comienzo y el desarrollo, para finalmente entregar una sensación de cierre que proporciona a la experiencia un sentido de realización y significado.

\footnotetext{
Una experiencia tiene una unidad que le da su nombre: esa comida, esa tormenta, esa ruptura de una amistad. La existencia de esta unidad está constituida por una cualidad única que impregna toda la experiencia a pesar de la variación de sus partes. Esta unidad no es emocional, práctica ni intelectual, ya que estos términos nombran distinciones que la reflexión puede hacer dentro de ella (Dewey, 1934, p. 38).
}

Las experiencias estéticas de Dewey y su unidad pueden relacionarse con lo que Mihaly Csikszentmihalyi identifica como el flujo, un estado en el que existe un objetivo claro y un sentido de certeza que permiten, a quienes viven la experiencia, ser absorbidos por ella sin esfuerzo (Csikszentmihalyi, 2014). Esta forma más bien coreográfica de entender las experiencias ha influido fuertemente en la literatura de la HCI y en el diseño de interacciones, que reconoce que el diseño para la experiencia es mucho más complejo que el diseño para la usabilidad, o incluso que el diseño para la experiencia de usuario (McCarthy y Wright, 2004). El diseño para la experiencia requiere conectarse empáticamente con los demás (Wright y McCarthy, 2008), así como compren- of living. The meaningfulness of such experiences was determined by the relationship between the living creature and the conditions offered by their surrounding environment. He describes aesthetic experiences as flowing from one determined point to another, as well as showing an organized movement. An aesthetic experience (or having an experience, according to him) embodies a whole unity of events bringing a sense of fulfillment, where the one who is experiencing the flow looks forward to the outcome to occur, while at the same time focusing on the process itself, including a series of events unfolding during the flow (Dewey, 1934). In other words, aesthetic experiences show rhythmic successions of movement, including commencement and development, to finally deliver a sense of closure, which grants meaning and fulfillment to the experience.

An experience has a unity that gives it its name, that meal, that storm, that rupture of friendship. The existence of this unity is constituted by a single quality that permeates the entire experience in spite of the variation of its constituent parts. This unity is neither emotional, practical, nor intellectual, for these terms name distinctions that reflection can make within it (Dewey, 1934, p. 38).

Dewey's aesthetic experiences and their unity can be related with what Mihaly Csikszentmihalyi identifies as the flow, a state in which there is a clear goal and a sense of certainty allowing those living the experience to be effortlessly absorbed by it (Csikszentmihalyi, 2014). This rather choreographic way of understanding experiences has had a strong influence in $\mathrm{HCl}$ and Interaction Design literature, which acknowledges that designing for experience is far more complex than designing for usability, or even for user experience (McCarthy \& Wright, 2004). Designing for experience requires connecting empathically with others (Wright \& McCarthy, 2008), as well as understanding nuanced aspects of their every- 
der los matices de sus motivaciones cotidianas y los rituales que existen tras las experiencias (Hassenzahl, 2010). Entre algunos de los marcos que nos guían para facilitar las experiencias estéticas con la tecnología, el que ofrecen Forlizzi y Battarbee (2004), por ejemplo, distingue tres categorías de modelos de experiencia: centrado en productos, centrado en usuarios y centrado en una perspectiva experiencial de la combinación de ambos. Este marco considera las interacciones producto-usuario de naturaleza situada (fluidas, cognitivas y expresivas), así como el tipo de experiencias que los usuarios encuentran cuando interactúan con productos (experimentar, tener una experiencia y co-experimentar). Del mismo modo, para Petersen, Iversen, Krogh y Ludvigsen (2004), la estética no puede surgir de una visión descontextualizada sobre los objetos, sino que debe hacerlo como una experiencia de uso situada. A su vez, Löwgren (2009) ofrece un conjunto de conceptos para articular la naturaleza temporal de la estética de la interacción: maleabilidad, ritmo, estructura dramática y fluidez. Estos conceptos capturan el flujo rítmico de la experiencia cotidiana que describe Dewey, especificando aspectos contenidos en esos sistemas interactivos que conducen a experiencias estéticas en contextos cotidianos.

En la siguiente sección presento una versión condensada de la manera generativa con la que Gendlin comprende la forma en que los organismos están conectados en un flujo de encuentros, de manera similar a lo que se describe como la estructura rítmica de las experiencias estéticas (Gendlin, 2012). La descripción de este modelo puede estar relacionada con aspectos de la transparencia en la interacción con el mundo, que se refiere al proceso mediante el cual los usuarios actúan a través de artefactos como parte de su encarnación (Ihde, 2010). Sin embargo, la importancia de presentar el modelo de Gendlin no radica necesariamente en el flujo en sí mismo, sino en lo que sucede cuando el flujo se interrumpe. Sostengo que, si bien las experiencias estéticas suceden cuando actuamos satisfactoriamente a través de artefactos, trascendiendo su calidad material (Hassenzahl, 2010), la transparencia no siempre es un prerrequisito necesario para que surjan encuentros estéticos con la tecnología. day motivations and rituals behind experiences (Hassenzahl, 2010). As some of the frameworks that guide us to facilitate aesthetic experiences with technology, Forlizzi and Battarbee (2004) for instance, distinguish three categories of models of experience: centered on products, centered on users, and centered on an experiential view on the combination of both. This particular framework considers situated product-user interactions (fluid, cognitive, and expressive), as well as the type of experiences the users encounter when interacting with products (to experience, to have an experience, and to co-experience). Similarly, for Petersen, Iversen, Krogh, and Ludvigsen (2004), aesthetics cannot emerge from a decontextualized view on objects, but rather as a situated experience of use. Löwgren (2009) offers a set of concepts to articulate the temporal nature of interaction aesthetics: pliability, rhythm, dramaturgical structure, and fluency. These concepts capture the rhythmic flow of everyday experience mentioned by Dewey, describing aspects contained in those interactive systems leading to aesthetic experiences in quotidian contexts.

In the following section, I introduce a condensed version of Gendlin's generative way to understand how organisms are connected in a flow of encounters, in a similar fashion to what is described as the rhythmic structure of aesthetic experiences (Gendlin, 2012). The description of this model can be related to aspects of transparency in the interaction with the world, which refers to the process by which users act through artifacts, as part of their embodiment (Ihde, 2010). The importance of introducing Cendlin's model, however, is not necessarily placed on the flow itself, but instead on what happens when the flow is interrupted. I argue that, although aesthetic experiences happen when we satisfactorily act through artifacts transcending its material quality (Hassenzahl, 2010), transparency is not necessarily always a precondition for the emergence of aesthetic encounters with technology. 
GENDLIN: EXPERIENCIAS ESTÉTICAS DENTRO

\section{Y MÁS ALLÁ DEL FLUIR}

Una de las principales características de las experiencias estéticas se relaciona con su dimensión encarnada, sensorial y emocional (McCarthy y Wright, 2004). Atendiendo a la centralidad del cuerpo en el proceso de interacción (Höök et al., 2018), proliferan teorías importadas de disciplinas ajenas al diseño de interacción, las que enriquecen la discusión sobre la naturaleza de la estética de la interacción. Han sido particularmente relevantes las teorías de filósofos como Merleau-Ponty (1962), Shusterman (2011) y Dewey (1934), las cuales han tenido una influencia significativa en la aparición de una miríada de publicaciones relevantes acerca del tema (Dourish, 2001; Höök, 2018; McCarthy \& Wright, 2004, 2005; Svanæs, 2013 , solo por nombrar algunas). Ofreciendo una perspectiva diferente, la filosofía de lo implícito de Eugene Gendlin, que se centra precisamente en las relaciones entre el cuerpo y la construcción de significado, tiene el potencial de contribuir no solo a través de un modelo que permite comprender cómo se constituyen las interacciones, sino también proporcionando una visión de cómo se pueden sistematizar las experiencias estéticas. Esta sección explica brevemente parte de la visión de Gendlin, para luego discutir temas relacionados con la estructura de las experiencias estéticas de acuerdo con el pragmatismo de Dewey.

Gendlin se distancia del concepto tradicional de percepción y se acerca a un modelo de interacción que entiende al entorno y al cuerpo como partes de una relación holística. En su modelo procesal, Gendlin $(1981,2012)$ rechaza la tesis de que el cuerpo y el entorno estén necesariamente divididos y propone, por el contrario, que están relacionados a través de secuencias de implicaciones y ocurrencias en las que los propios organismos funcionan como entornos. La secuencia de implicación y ocurrencia es, por algunos de sus elementos, similar al concepto de affordances y nichos de Gibson (1977), donde los objetos y el entorno coexisten como entidades complementarias. Sin embargo, el modelo procesal de Gendlin va más allá de la relación con objetos tangibles en el entorno, exten-
GENDLIN: AESTHETIC EXPERIENCES IN AND BEYOND THE FLOW

One of the main characteristics of aesthetic experiences relates to their embodied, sensory, and emotional dimension (McCarthy \& Wright, 2004). Attending to the centrality of the body in the process of interaction (Höök et al., 2018), the emergence of theories imported from disciplines outside Interaction Design has flourished, enriching the discussion around the nature of interaction aesthetics. Particularly relevant have been the theories of philosophers such as Merleau-Ponty (1962), Shusterman (2011), and Dewey (1934), that have had significant influence in the emergence of a myriad of relevant publications in the area (Dourish, 2001; Höök, 2018; McCarthy \& Wright, 2004, 2005; Svanæs, 2013, just to name a few). As a different perspective, Eugene Gendlin and his philosophy of the implicit, which centers on the relations between the body and meaning, has the potential to contribute not only by offering a model of understanding how interactions are constituted, but also by providing a view on how aesthetic experiences can be systematized. This section briefly explains part of Gendlin's view, to then discuss issues regarding the structure of aesthetic experiences, according to Deweyan pragmatism.

Gendlin distances himself from the traditional concept of perception towards an interactional model that understands the environment and the body as engaged in a holistic relationship. In his 'process model' (Cendlin, 1981, 2012), he rejects the thesis that the body and the environment are necessarily split, proposing instead that they are related through sequences of implying and occurring, where organisms function as environments themselves. The implying and occurring sequence is, in some elements, similar to Gibson's (1977) concept of affordances and niches, where objects and environment coexist as complementary entities. However, Gendlin's process model goes beyond the relationship with 
diendo este dominio a otras dimensiones simbólicas de la experiencia y la interacción.

Propongo que el organismo activo hace algo que yo llamo "implicación". Implica el medio ambiente. El ambiente puede ocurrir o no ocurrir como lo implica el cuerpo. La implicación y la ocurrencia son dos funciones interdependientes que crean un proceso. En lugar de que el cuerpo y el medio ambiente sean dos cosas, distingamos entre la implicación y la ocurrencia y expliquemos cómo sus funciones se requieren mutuamente. Si lo que he dicho sobre el cuerpo y el medio ambiente es cierto, entonces no puede existir el uno sin el otro, porque lo que cada uno es implica lo que es el otro. Juntos, la implicación y la ocurrencia comienzan a conceptualizar la relación inherente del cuerpo-ambiente (Gendlin, 2012, p. 146).

Para ejemplificar con algo simple la secuencia de implicación y ocurrencia, supongamos que tenemos un organismo corporizado que necesita respirar para seguir viviendo. Respirar implica que el oxígeno ingrese al cuerpo. Lo que ocurre a continuación es que, al respirar, el organismo libera dióxido de carbono; el hecho de vaciar el contenido de los pulmones implica respirar aire fresco una vez más. Esta función tiene otras implicaciones y ocurrencias que se desarrollan como secuencias generativas, como el hecho de que el organismo está vivo en un entorno determinado, afectando de diferentes maneras el proceso de otros organismos. Este proceso de avance permite a los organismos vivir. La separación entre el medio ambiente y el cuerpo solo ocurre cuando los recursos que el cuerpo necesita para vivir (por ejemplo, el oxígeno) no están accesibles. En tal caso, el cuerpo entra en un proceso de "implicación reiterativa" o estancamiento que le impide al organismo desempeñar su papel (Gendlin, 2012). Para Gendlin, los procesos de implicación y ocurrencia también se pueden traducir en la complejidad de los patrones simbólicos humanos (como el lenguaje, el arte y la música), que también están encarnados. Estos patrones secuenciales generan cambios en el cuerpo humano, los cuales influyen en los cambios situacionales y ofrecen innumerables posibilidades de tangible objects in the environment, extending this domain to other symbolic dimensions of experience and interaction.

I propose that the active organism does something I call 'implying'. It implies the environment. The environment may or may not occur somewhat as the body implies. Implying and occurring are two interdependent functions that create one process. Instead of body and environment being two things, let us distinguish between implying and occurring and spell out how their functions require each other. If what I have said about body and environment is true, then they cannot exist without each other because what each is involves what the other is. Together implying and occurring-into begin to conceptualize the inherent relation of body-environment (Gendlin, 2012, p. 146).

As a simple example to illustrate the implying and occurring sequence, we have a bodied organism that needs to breathe to keep living. Breathing implies that oxygen enters the body. What occurs next is that by breathing, the organism releases carbon dioxide, so by emptying the content of the lungs, it implies breathing fresh air once again. This function has other implications and occurrences that develop as generative sequences, such as the fact the organism is alive in a determined environment, affecting the process of other organisms in different ways. This carrying-forward process allows organisms to live. The separation between environment and body only occurs when the resources the body needs to live (for example, oxygen) are not accessible. In such a case, the body enters a process of 'reiterative implying' or stillness, which prevents the organism from performing its role (Gendlin, 2012). For Gendlin, processes of implying and occurring can also be translated to the complexity of human symbolic patterns (such as language, art, and music), which are also embodied. These sequential patterns generate shifts in the human body that influence 
comportamiento o formas de interacción. En algunos casos, estas secuencias parecen más importantes y memorables que otras. Cuando una experiencia estética ocurre, se consuma una sensación de construcción de significado individualizado que se fusiona con el proceso continuo de fluir, permitiendo que se desarrolle el proceso de avance (Gendlin, 2012). Este proceso se relaciona con el concepto de la experiencia estética entrelazada con la vida cotidiana, como la definiera Dewey (1934). Tal como en el caso de la teoría de la implicación reiterativa de Gendlin, para Dewey (1934) la estasis o las fijaciones son las faltas que disipan las cualidades esenciales de las experiencias. Sin embargo, no debemos pensar que todas las experiencias estéticas deben fluir ininterrumpidamente para ser significativas, sino que deben moverse o avanzar frente a una dificultad o un conflicto. Dewey describe esta tensión como un "estado de maduración" (Dewey, 1934 p. p. 42) en el que las dificultades sucesivas nos recompensan con el sentido de las experiencias estéticas. Del mismo modo, Gendlin denominaba este proceso de gestionar las dificultades de la vida como "seguir adelante", en el que la persona se involucraría en un proceso deliberado de toma de consciencia, facilitando su transformación y, al mismo tiempo, construyendo significado a partir de la situación (Gendlin, 1978).

Es común ver una tendencia errónea que interpreta las experiencias estéticas como necesariamente positivas y, de alguna manera, vinculadas con la satisfacción instantánea. Es cierto que diseñar para habilitar un flujo de eventos puede facilitar el surgimiento de experiencias estéticas, permitiendo a los usuarios actuar a través de artefactos de manera placentera. Sin embargo, debido a su calidad transformadora, el concepto de "implicación reiterativa", introducida como posible fricción de diseño, aparece como un camino viable para facilitar la aparición de significado.

\section{HEIDEGGER Y LA ACTUACIÓN A TRAVÉS}

\section{DE ARTEFACTOS}

Se ha importado a la HCI una serie de teorías filosóficas que intentan explicar la relación entre el cuerpo y la interacción a través de herramientas. Winograd y situational changes, offering countless behavioral possibilities or ways of interacting. In some cases, these sequences seem more important and memorable than others. When an aesthetic experience occurs, a sense of individualized meaningfulness is consummated and merged with the ongoing process of flowing, allowing the process of carrying forward to take place (Gendlin, 2012). This process relates to the concept of aesthetic experience as blended with everyday living as defined by Dewey (1934). As in the case of Gendlin's theory of reiterative implying, for Dewey (1934) stasis or fixations are the sins that remove experiences from their essential quality. But we should not think that all aesthetic experiences need to flow uninterruptedly to be meaningful, but instead, they need to show movement or to carry forward in case of struggle and conflict. Dewey describes this tension as a 'state of maturation' (Dewey, 1934. p. 42), where succeeding difficulties reward us with the meaningfulness of aesthetic experiences. Similarly, for Gendlin this process of managing the struggle of living was referred to as carrying forward, in which the person would engage in a conscious process of becoming aware, facilitating its transformation whilst building meaning from the situation (Gendlin, 1978).

It is common to see an erroneous tendency that interprets aesthetic experiences as being necessarily positive and somehow linked with instant satisfaction. It is true that designing to enable an effortless flow of occurrences can facilitate the emergence of aesthetic experiences, allowing users to act through artifacts pleasantly. However, due to its transformative quality, the concept of reiterative implying introduced as possible design friction appears as a viable path to facilitate the emergence of meaning.

\section{HEIDEGGER AND ACTING THROUGH}

\section{EQUIPMENT}

A series of philosophical theories have been imported to $\mathrm{HCl}$ trying to explain the relationship 
Flores (1986) fueron pioneros en la introducción de la teoría de Heidegger sobre el manejo de herramientas y su énfasis en la consciencia del contexto a través de la acción, lo que ha influido profundamente en el campo de las tecnologías para que sean transparentes a través del uso, de modo que el usuario pueda centrarse en la tarea que ejecuta y no en el artefacto (Dourish, 2001).

Para Heidegger, el ser-a-la-mano representa la participación a través de la praxis, que es la forma natural en que el mundo se revela (Ihde, 2010). Este estado se describe como un modo de consciencia que involucra la acción experta de actuar a través de una herramienta (Winograd y Flores, 1986). En el estado ser-a-la-mano, el descubrimiento del mundo que nos rodea está necesariamente implícito (Ihde, 2010). De manera similar, para Merleau-Ponty nuestra consciencia no-temática se convierte en el estado a través del cual nuestros cuerpos exploran nuestro entorno sin ser interrumpidos por representaciones mentales (Romdenh-Romluc, 2010). Si tomamos el ejemplo tradicional de martillar un clavo, el manipulador no es consciente del martillo como un objeto explícito de consciencia, sino que está inmerso en realizar la acción de golpear el clavo. En este caso, el martillo se vuelve transparente y el manipulador actúa a través de él. Cuando se produce un quiebre, el fluir con nuestro ser-en-el-mundo se interrumpe a medida que la herramienta se revela y queda disponible para su representación. En este momento, cuando surge la consciencia del artefacto, este comienza a ser-a-la-vista (Ihde, 2010). Si el individuo repentinamente se da cuenta de tal relación y la herramienta comienza a aparecer en su consciencia, parte de las sucesiones rítmicas de los movimientos expertos se interrumpirían. Como lo dijera Verbeek:

La participación de una persona en la realidad se lleva a cabo a través del artefacto siendo-a-la-mano. Es solo cuando esto se quiebra que vuelve a pedir atención. Es entonces que el artefacto está, en palabras de Heidegger, "siendo-a-la-vista" y ya no puede facilitar una relación entre un usuario y su mundo (2006, p. 364). between body and interaction through tools. Winograd and Flores (1986) pioneered the introduction of Heidegger's theory of tool handling and its emphasis on context awareness through action, which has profoundly influenced the field in technologies to become transparent through use, so that the user can focus on the task they perform rather than the artifact (Dourish, 2001).

For Heidegger, ready-to-hand represents involvement through praxis, which is the natural way the world discloses itself (Ihde, 2010). This state is described as a mode of consciousness involving skilled action of acting through a piece of equipment (Winograd \& Flores, 1986). In the ready-to-hand state, the discovery of the world that surrounds us is necessarily implicit (Ihde, 2010), in a similar way for Merleau-Ponty our unthematized consciousness becomes the state through which our bodies explore our surroundings without being interrupted by mental representations (Romdenh-Romluc, 2010). If we take the traditional example of hammering a nail, the manipulator is not aware of the hammer as an explicit object of consciousness, but rather immersed in performing the action of hitting the nail. In this case, the hammer becomes transparent, and the manipulator acts through it. When a breakdown occurs, the flow with our being in the world is interrupted, as the thing reveals itself and becomes available for its representation. At this moment when unreadiness to hand emerges, the artifact becomes present-at-hand (Ihde, 2010). If suddenly, the individual becomes aware of such a relationship and the tool starts appearing to her consciousness, part of the rhythmical successions of skilled movements would be interrupted. As stated by Verbeek:

A person's involvement with reality takes place through the ready-to-hand artifact. Only when it breaks down does it ask attention for itself again. The artifact is then, in Heidegger's words, 'present-at-hand' and is not able to 
El estado de ser-a-la-vista tiene una connotación negativa en $\mathrm{HCI}$, ya que el fin de la mayoría de los sistemas interactivos es funcionar sin interferir con el estado del fluir del usuario. Sin embargo, es esencial tener en cuenta que tan pronto como los objetos están disponibles para nuestra consciencia, quedan abiertos al escrutinio, al análisis (Ihde, 2010) e incluso a la participación creativa (Dreyfus, 1991).

\section{MARCO TEÓRICO: HACIA UNA COMPRENSIÓN} SISTEMÁTICA DE LAS EXPERIENCIAS

\section{ESTÉTICAS}

En esta sección presento un marco teórico que discute cómo se desarrollan las experiencias estéticas de acuerdo con diferentes tipos de relaciones encarnadas con artefactos tecnológicos: (1) transparencia, (2) dialogar con el artefacto, (3) diseñar obstáculos para el fluir, y (4) el quiebre. Estas facilitan la aparición de significado de diferentes maneras, actuando a través de objetos transparentes o dialogando con su presencia. La transparencia de la tecnología se utiliza como punto de partida en este artículo, ya que históricamente se ha considerado como una condición ideal para el diseño de artefactos e interfaces útiles (Weiser, 1991). Una tecnología que compite por nuestra atención, en lugar de permitir nuestro actuar durante la interacción, puede ser rechazada por inutilizable o engorrosa. Sin embargo, este no es siempre el caso: una tecnología disponible para nuestro análisis puede volverse estética, tal como se analiza a continuación.

\section{Caso 1: Transparencia}

Hace casi tres décadas, Weiser (1991) afirmó que las interfaces transparentes permanecerían en el fondo de nuestra consciencia, liberándonos de la lucha contra las tareas domésticas y abriendo espacios para la socialización y la autorrealización. Una fotógrafa que actúa a través de su cámara, extendiendo su influencia corpórea al capturar una imagen, es un ejemplo de "actuar a través de", un estado que filósofos como Merleau-Ponty (1962) reconocieron como nuestra consciencia no-tematizada e infalible, o la puerta para nuestra interacción encarnada en el mundo. Como di- facilitate a relationship between a user and his or her world anymore (2006, p. 364).

The state of present-at-hand carries with a negative connotation in $\mathrm{HCl}$, as the end of the majority of interactive systems is to function without interfering with the user's state of flow. However, it is essential to take into account that as soon as objects become available to our consciousness, they become open for scrutiny, analysis (Ihde, 2010), and even creative engagement (Dreyfus, 1991).

\section{FRAMEWORK: TOWARDS A SYSTEMATIC UN- DERSTANDING OF AESTHETIC EXPERIENCES}

In this section, I introduce a theoretical framework discussing how aesthetic experiences unfold according to different types of embodied relations with technology artifacts: (1) transparency, (2) dialoguing with equipment, (3) design obstacles to the flow, and finally, (4) the breakdown. These facilitate the emergence of meaning in different ways, by acting through transparent objects, or conversely dialoguing with their presence. Transparency of technology is used as a starting point in this paper, as it has been historically considered as an ideal condition for the design of useful artifacts and interfaces (Weiser, 1991). A piece of technology that competes with our attention, instead of enabling our performance during interaction, might be rejected as unusable or cumbersome. However, this is not always the case, and a piece of technology available for our analysis can potentially become aesthetic as discussed below.

\section{Case 1: Transparency}

Almost three decades ago, Weiser (1991) claimed that transparent interfaces would remain in the background of our consciousness, freeing us from the struggles of menial tasks and opening spaces for socialization and self-realization. A photographer that acts through her camera, extending her embodiment and capturing a shot, is an example 
jimos, Heidegger también describió este estado como ser-a-la-mano, en el que el usuario está inmerso en el uso del artefacto (Dreyfus, 1991). En el ejemplo anteriormente mencionado, las cualidades habilitadoras del artefacto diseñado median la experiencia estética, ya que esta proviene de la satisfacción de haber capturado esa toma específica entre miles de otras. Si observamos el modelo procesal de Gendlin (1981, 2012), la transparencia de la tecnología funcionaría como el flujo ininterrumpido de acciones que conducen a la ocurrencia de lo que el organismo implica, del mismo modo que la fotógrafa espera capturar una toma de acuerdo con su plan. Esta acción podría estar respaldada por una serie de decisiones de diseño relacionadas con el objeto en sí mismo, como su aspecto, su textura, su forma o su materialidad, lo que permite una acción mediada de manera placentera.

Sin embargo, en algunos casos las experiencias estéticas facilitadas por nuestra interacción con los objetos pueden trascender la presencia material del artefacto en sí mismo. Para ejemplificar esto mediante un producto, Hassenzahl (2010) describe cómo la Wake-up Light desarrollada por Phillips, que podría parecer un objeto bastante discreto, demuestra su potencial cuando cumple su función: imitar la experiencia del despertar con la luz natural del sol (la lámpara utiliza la terapia de luz para facilitar un despertar suave, al contrario de lo que haría un reloj despertador). En este caso, aunque la realidad material del objeto sí importa, sus cualidades físicas son superadas por la experiencia que puede ofrecer durante su funcionamiento.

Es importante tener en cuenta que la transparencia de las interfaces podría no ser necesariamente una condición previa para el surgimiento de experiencias estéticas. Según Dewey (1934), se considera que las experiencias irrelevantes, incluyendo aquellas que contienen sucesiones dispersas o coreografías rígidas, tienden a desaparecer debido a su carencia de significado. Consideremos el ejemplo de lavar los platos: se trata de una experiencia irrelevante en la cual la esponja se vuelve transparente para nuestra consciencia, ya que es posible que ni siquiera pense- of 'acting through', a state that philosophers such as Merleau-Ponty (1962) recognized as our infallible unthematized consciousness, or the door for our embodied engagement with the world. As we said, Heidegger also described this state as ready-to-hand, where the user is immersed in the use of equipment (Dreyfus, 1991). In the example mentioned above, the enabling qualities of the designed artifact mediate the aesthetic experience, as it comes from the satisfaction of having captured that specific shot amongst a thousand others. Looking through the lenses of Gendlin's process model $(1981,2012)$, transparency of technology would work as the uninterrupted flow of actions leading to the occurrences of what is implied by the organism; in the same way, the photographer expects to capture a shot according to her plan. This action might be supported by a series of design decisions related to the object in itself, such as the look, texture, shape, and materiality of the object, enabling mediated action in a pleasurable way.

In some cases, however, aesthetic experiences facilitated by our interaction with objects might transcend the material presence of the artifact itself. To exemplify this employing a product, Hassenzahl (2010) describes how the Wake-up Light developed by Phillips might appear as a rather unobtrusive object; however, when functioning by mimicking the experience of waking up with natural sunlight, it unfolds its potential. The lamp uses light therapy to facilitate a gently awakening, in contrast with an alarm clock. In this case, although the material reality of the object certainly matters, its physical qualities are surpassed by the experience it can provide during its functioning.

It is important to consider that transparency of interfaces might not necessarily be a precondition for the emergence of aesthetic experiences. According to Dewey (1934), unremarkable experiences, or even those containing loose successions or rigid choreographies, are deemed to disappear 
mos mucho en la tarea misma mientras lavamos. En este caso, actuar a través de la esponja no garantiza la aparición de cualidades estéticas, sino que meramente facilita una acción. Es particularmente interesante el caso de los objetos que se conectan de manera visceral con nuestras emociones (Norman, 2013), en el que el uso diario podría causar el desvanecimiento significativo de la sensación de novedad y emoción ligada a la interacción.

\section{Caso 2: Diálogo con el artefacto}

Aunque los artefactos interactivos generalmente deberían permitir actuar a través de ellos utilizando la transparencia, es importante distinguir que la aparición de la tecnología en nuestra consciencia es a veces necesaria para darle sentido a la interacción, particularmente cuando el sistema está diseñado para tener en cuenta el cuerpo en su totalidad. Inspirados por la idea de Heidegger de actuar a través de artefactos, propusimos el término poético presente-en-el-cuerpo (Núñez-Pacheco y Loke, 2014), que considera la aparición de la consciencia encarnada durante la interacción, un aspecto que no siempre se toma en consideración. Al presentar este término no pretendimos ofrecer una traducción directa de la complejidad de las ideas de Heidegger, sino sugerir un concepto sensibilizador para expandir la discusión actualmente en curso en HCi (Núñez-Pacheco y Loke, 2014). Esta definición expresiva no alude a lo que está siendo-a-lavista (ya que, en ese caso, los objetos se presentan ante nuestra consciencia para su análisis y, sin embargo, no actuamos a través de ellos), como tampoco sugiere precisamente lo que está siendo-a-la-mano (donde actuamos a través de objetos en un estado de inmersión total, sin analizar la relación entre artefacto y acción) (Dreyfus, 1991; Ihde, 2010). Tomando distancia de esos conceptos, presente-en-el-cuerpo se refiere a encuentros significativos con sistemas interactivos que aparecen diseñados como un diálogo reflexivo y abierto a teorizaciones entre el artefacto y el cuerpo del usuario. Esta disponibilidad mutua está destinada a generar reflexiones e ideas significativas, las cuales son algunas de las condiciones previas para la apari- as meaningless. Consider the example of washing the dishes: an unremarkable experience, where the sponge becomes transparent to our consciousness, as we might not even think much about the task of washing whilst performing it. In this case, acting through the sponge does not ensure the emergence of aesthetic qualities, but instead facilitates an action. Particularly interesting is the case of objects connecting in visceral ways with our emotions (Norman, 2013), in which everyday use might dramatically fade away the novelty and excitement tied to interaction.

\section{Case 2: Dialoguing with equipment}

Although interactive artifacts should generally enable acting through them using transparency, it is important to distinguish that the appearance of technology to our consciousness is sometimes necessary to make sense of the interaction, particularly when the system is designed with the engagement of the full body in mind. Inspired by Heidegger's idea of acting through artifacts, we proposed the poetic term present-at-body (Núñez-Pacheco \& Loke, 2014) which considers the appearance of embodied awareness during the interaction - an aspect that is not always taken into account. By introducing this term, we did not aim to offer a direct translation on the complexity of Heidegger's ideas, but rather to suggest a sensitizing concept to expand the ongoing discussion in $\mathrm{HCl}$ (Núñez-Pacheco \& Loke, 2014). This expressive definition is neither present-at-hand (as in that case objects appear to our consciousness for analysis, yet we do not act through them) nor precisely ready-to-hand (where we act through objects in a complete state of immersion, without scrutinizing the relationship between equipment and action) (Dreyfus, 1991; Ihde, 2010). Taking distance from those concepts, present-at-body refers to meaningful encounters with interactive systems that appear designed as a thoughtful dialogue between the artifact and the user's body, in which this dialogue is 
ción de experiencias estéticas. Hay quienes podrían argumentar que aquello presente-en-el-cuerpo podría ser simplemente un caso de ser-a-la-mano, ya que el sujeto actúa y fluye a través de la interacción con el artefacto. Sin embargo, y aunque la diferencia puede ser sutil, el ser-a-la-mano no implica necesariamente que la persona que actúa se encuentra en un estado de consciencia de su realidad encarnada. Por lo tanto, ser-a-la-mano no está teorizando la interacción, algo que sí ocurre en la situación de presencia en el cuerpo. Consideramos que esta distinción es necesaria para desafiar la comprensión binaria de transparencia-quiebre que prevalece en la HCI (Núñez-Pacheco \& Loke, 2014).

YU es un ejemplo de una tecnología que facilita un diálogo encarnado. Se trata de un sistema de meditación desarrollado por Zhu, Zhang, Ma y Li (2015) inspirado en el concepto de aceptación incondicional derivado de la estética china. YU recopila los datos de los latidos del corazón del usuario, los que se representan como peces en un estanque (Figura 1). En lugar de seguir un enfoque numérico y científico de los datos personales (algo bastante común en las pulseras de seguimiento automático), el sistema invita a los usuarios a apreciar la belleza de sus ritmos internos. El significado de lo que ocurre en el estanque permanece abierto a la interpretación del usuario. En este caso, la tecnología se revela a medida que el usuario va alternando el foco de su consciencia entre el ritmo de su corazón y la respuesta del sistema. Como parte de la interacción con el artefacto, el usuario está totalmente presente en su cuerpo, así como en las visualizaciones en el estanque. A través de la perspectiva del modelo procesal de Gendlin, el sistema facilita la aparición de ocurrencias (significado) en un flujo o diálogo entre el artefacto y el cuerpo del usuario.

\section{Caso 3: Diseño de obstáculos para el fluir}

A veces las interfaces interactivas y los artefactos se diseñan para representar dificultades, constituyéndose en un recurso para favorecer la generación de significado. En este caso, la dificultad en cuestión debe ser experiencial más que técnica ya que, si el sistema no funcionara correctamente, esta incapacidad de ser-a- open for theorizations. This availability of both is intended to generate significant reflections and insights, which are some of the preconditions for the appearance of aesthetic experiences. Some might argue that present-at-body might be a case of ready-to-hand after all, as the subject still acts and flows through the interaction with the artifact. However, although the difference might be subtle, in ready-to-hand the person who enacts is not necessarily in a state of conscious awareness of her embodied reality, therefore is not theorizing the interaction as it happens in the presentat-body situation. We consider the distinction is necessary to defy the binary understanding of transparency versus breakdown prevalent in $\mathrm{HCI}$ (Núñez-Pacheco \& Loke, 2014).

As an exemplar of a technology that facilitates an embodied dialogue, $Y U$ is a system for meditation developed by Zhu, Zhang, Ma, and Li (2015) inspired by the concept of non-judgmental acceptance and derived from Chinese aesthetics. yu collects the user's heartbeat data, which is represented as fish in a pond (Figure 1). Rather than following a numeric, scientific approach to self-data (quite common in the case of self-tracking wristbands), the system aims to encourage users to appreciate the beauty of their inner rhythms. The meaning of what is occurring in the pond remains open for the user's interpretation. In this case, technology reveals itself, as the user is shifting the awareness between the rhythm of her heart and the system's response. As part of the interaction with the artifact, the user is fully present in her body and the direct output generated as visualizations in the pond. Through the lenses of Gendlin's process model, the system facilitates the emergence of occurrences (meaning) in a flow or dialogue between the artifact and the user's body.

\section{Case 3: Designing obstacles to the flow}

Sometimes interactive interfaces and artifacts are designed with struggle in mind, as a resource for 
la-mano podría referirse a un quiebre, como lo ejemplificaré en el próximo caso. Desde una perspectiva gendliana, la experiencia estética aparece como un ejercicio de superación a partir de una situación de implicación reiterativa. En algunos casos, las experiencias estéticas tienden a asociarse con el placer y la satisfacción instantáneos, un aspecto que ignora el poder transformador de un estado de conflicto controlado. El diseño de interacciones incómodas bajo ciertas limitaciones abre oportunidades para la aparición de vínculos sociales y sus significados compartidos, de manera similar a lo que ocurre con los ritos (Benford et al., 2012; Benford et al., 2018), un elemento que se ha explorado principalmente en el campo de los juegos interactivos. Aspectos tales como la ambigüedad, utilizados como recursos de diseño, pueden revelar oportunidades de interacción estética e interpretativa (Gaver, Beaver, \& Benford, 2003). El diseño de pequeñas fricciones dentro de la dinámica interactiva con artefactos puede, de hecho, apoyar la reflexión y desafiar la forma ausente con la que interactuamos con objetos (Cox, Gould, Cecchinato, Iacovides, \& Renfree, 2016). El restringir algunas opciones como forma de habilitar otras e incluso el diseñar para la contraintuitividad se utilizan como recursos para ralentizar la interacción y promover la curiosidad (Pierce \& Paulos, 2015). A veces, las experiencias estéticas surgen a partir de experiencias interactivas que fueron diseñadas teniendo en cuenta el conflicto y la tensión (Dalsgaard, 2014), lo que intensifica la sensación de madurez y satisfacción cuando se superan los obstáculos. Se podría argumentar que el conflicto o las dificultades son formas en las que el cuerpo se ve atrapado en una situación de implicación reiterativa y, por lo tanto, las condiciones no se cumplen y el fluir se detiene. Sin embargo, como se discutió anteriormente, las secuencias de implicación-ocurrencia son generativas y, cuando no se cumplen los requisitos, en algunos casos nos adaptamos a las condiciones existentes, abriendo espacios para nuevas redes y creando nuevos significados (Gendlin, 2012).

Un buen ejemplo de cómo un conflicto puede conducir a la generación de significado es Seeing is Believing, una instalación transdisciplinaria dise- the emergence of meaning. In this case, the struggle is meant to be experiential over technical, as if the system does not work properly such unreadiness-to-hand might refer to a breakdown, as I will later exemplify through examples in the next case. From a Gendlian perspective, the aesthetic experience appears as an exercise of carrying forward from a situation of reiterative implying. In some cases, aesthetic experiences tend to be associated with instant pleasure and satisfaction, an aspect that ignores the transformative power of a state of controlled struggle. The design of controlled uncomfortable interactions opens up opportunities for shared social meaning and bonding in a similar way as rites (Benford et al., 2012; Benford et al., 2018), an element that has been mainly explored in the field of interactive games. Aspects such as ambiguity used as a design resource can disclose opportunities for aesthetic and interpretative engagement (Gaver, Beaver, \& Benford, 2003). The design of small frictions within the interactive dynamics with artifacts can, in fact, support reflection, defying our absentminded approach of interacting with objects (Cox, Gould, Cecchinato, lacovides, \& Renfree, 2016). Enabling constraints, and even designing for counterintuitiveness has also been used to slow down interaction and promote curiosity (Pierce \& Paulos, 2015). Sometimes, aesthetic experiences emerge from interactive experiences designed with conflict and tension in mind (Dalsgaard, 2014), bringing an increased sense of maturation and fulfillment when carrying forward. It could be argued that conflict or struggle are ways in which the body is trapped in a situation of reiterative implying, and therefore the conditions are not met, and the flow stops. However, as previously discussed, the sequences of implying-occurring are generative, and when requirements are not met, in some cases, we adapt to the existing conditions, opening spaces for new networks and meaning-making (Gendlin, 2012). 
ñada por Eugenie Lee que destaca el tema del dolor crónico desde el punto de vista del arte y la ciencia (DeLosAngeles, 2018). Como dispositivo educativo, Seeing is Believing sumerge al público en una experiencia personalizada que utiliza el dolor en condiciones controladas para crear consciencia sobre la interconexión entre el cuerpo y la mente y sobre el estigma asociado al vivir con dolor crónico. La instalación consiste en una experiencia guiada con varias etapas. En una de ellas, la participante es guiada a una cámara anecoica donde se le pide que use un par de gafas de realidad virtual y un guante con simuladores de dolor (Figura 2). Una vez dentro de la cámara, la participante puede ver y sentir cómo su mano experimenta un proceso de deformación (Figura 3). La metáfora ilustra directamente la problemática de vivir con dolor crónico, conectando a las personas empáticamente con el problema. Habiendo experimentado la interacción por mí misma, puedo asegurar que la experiencia dentro de la cámara es inquietante y abrumadora. Sin embargo, ello no es impedimento para que los conocimientos adquiridos sobre el tema sean significativos y transformadores. El cuerpo ha experimentado angustia controlada durante el proceso; no obstante, como resultado se obtienen lecciones acerca de la propia condición humana.

\section{Caso 4: El quiebre}

Como una de las situaciones que surgen de un caso de ser-a-la-vista, el quiebre ocurre cuando el mal funcionamiento de un sistema o un objeto fuerza su aparición en nuestra consciencia (Dreyfus, 1991). Los objetos también aparecen en nuestra consciencia cuando un sistema es engorroso o cuando distrae o incomoda. Un quiebre implica un cambio de posición, desde la interacción con el objeto que sufre el mal funcionamiento hacia el contexto en el que ocurre la situación.

Diseñar sistemas que promueven experiencias estéticas en el contexto del mal funcionamiento es un desafío, pero el quiebre en sí mismo es una oportunidad para la observación, el compromiso creativo y el aprendizaje (Dreyfus, 1991; Winograd y Flores, 1986). Así como un paraguas roto podría propiciar una
A good example of how conflict can lead to meaningful insights, Seeing is Believing is a transdisciplinary installation designed by Eugenie Lee that highlights the issue of chronic pain from the standpoint of art and science (DeLosAngeles, 2018). As an educational device, Seeing is Believing immerses the audience in a personalized experience that uses pain under controlled conditions to raise awareness about the interconnection between body and mind, and the stigma associated with living with chronic pain. The installation consists of a guided experience that goes through different stages. In one passage, the participant is guided to an anechoic chamber, where she is asked to wear a pair of VR goggles and a glove containing pain simulators (Figure 2). Once inside the chamber, the participant can see and feel how her hand experiences a process of deformation (Figure 3). The metaphor quite directly illustrates the struggles of living with chronic pain, connecting people empathically with the problem. Having experienced the interaction firsthand, I am in a position to ensure the experience inside the chamber is disturbing and overwhelming. However, this is not an impediment for the insights gained into the issue to be significant and transformative. The body has experienced controlled distress during the process, yet lessons about the own human condition are learned as a result.

\section{Case 4: The Breakdown}

As one of the situations emerging from a present-at-hand case, the breakdown occurs when a malfunction in a system or an object forces its appearance in our consciousness (Dreyfus, 1991). Objects also appear in our consciousness when a system is cumbersome, distracting or uncomfortable. A breakdown implies a change of locus, from the interaction with the object that suffers from the malfunction to the context in which the situation happens.

The design of systems promoting aesthetic experiences in the context of malfunctions is 
Figura 1: Uno de los proto tipos del sistema yu. Créditos: Imagen proporcionada por la investigadora Bin (Tina) Zhu.

Figura 2: Seeing is Believing, por Eugenie Lee (unsw Galleries, Sídney, 2016). La artista junto al sistema. Fotografía: Anna Kucera. Reproducida con permiso de la artista Eugenie Lee.

Figura 3: Seeing is Believing, por Eugenie Lee (unsw Galleries, Sídney, 2016). La experiencia en realidad virtual dentro de la cámara, diseñada por Andrew Burrell. Fotografía: Andrew Burrell. Reproducida con permiso de la artista Eugenie Lee.

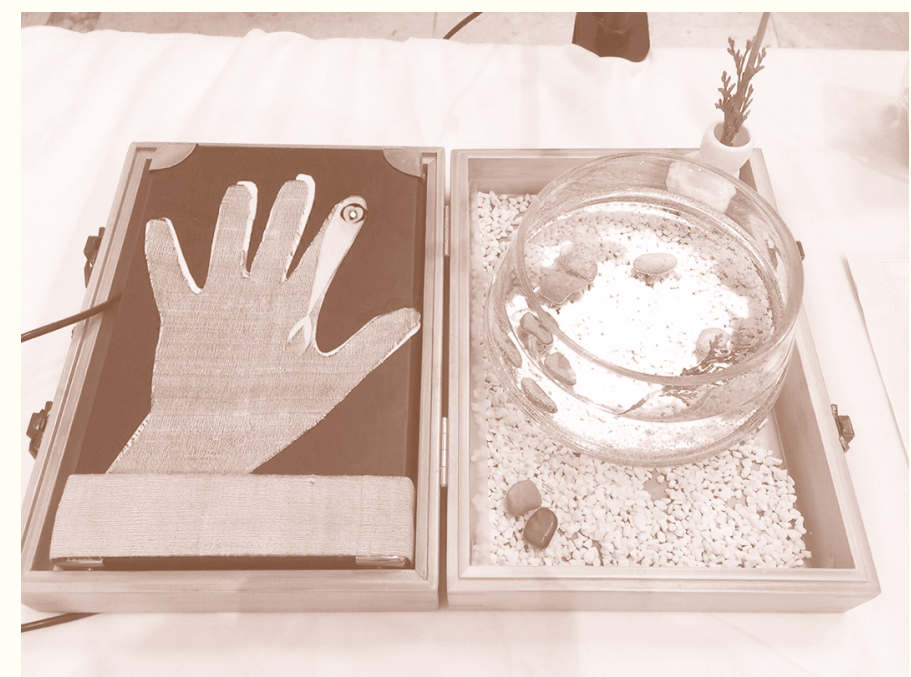

Figure 1: One of the prototypes of the vu system. Credits: Image provided by the researcher Bin (Tina) Zhu.
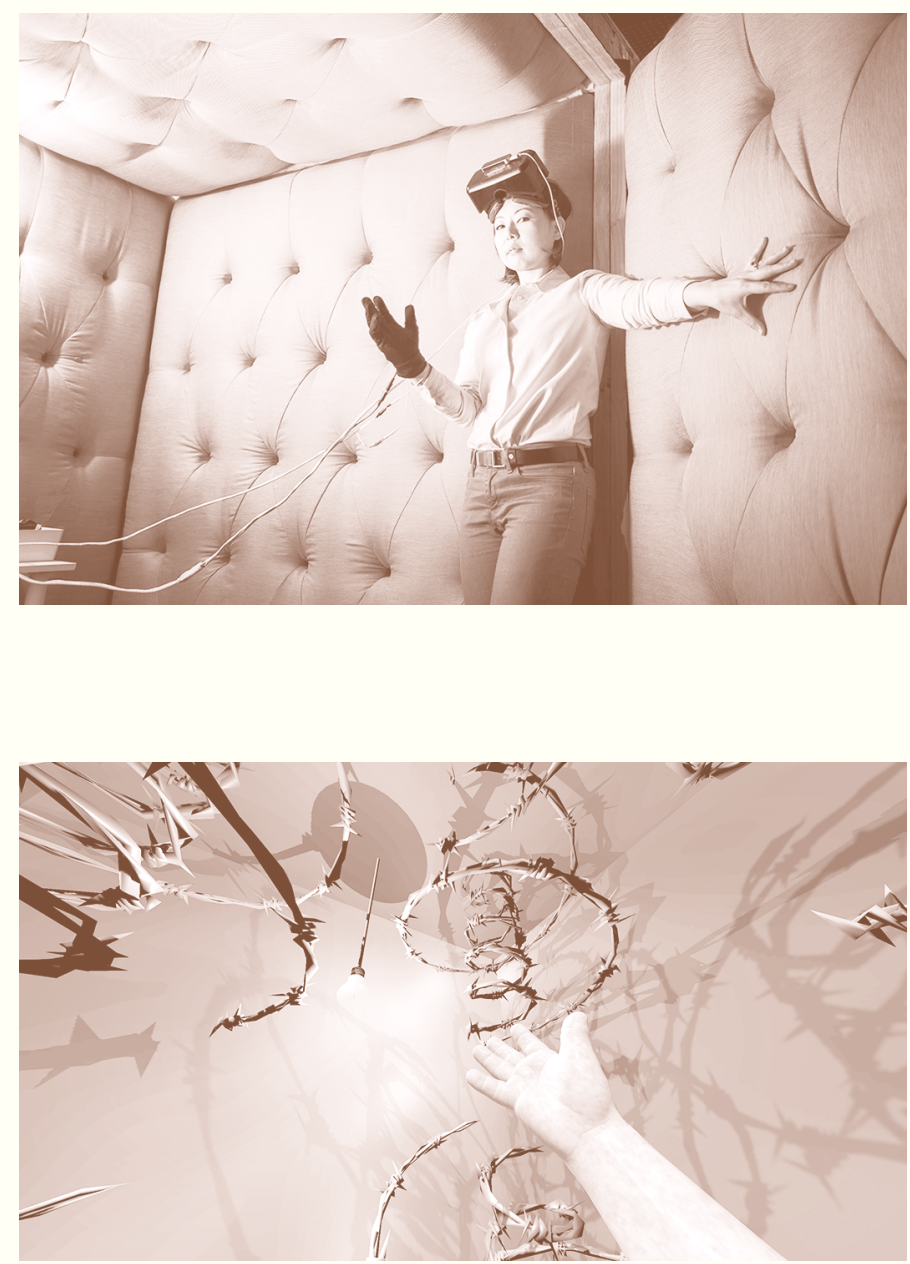

Figure 2: Seeing is Believing, by Eugenie Lee (unsw Galleries, Sydney, 2016). The artist and the system. Photograph: Anna Kucera. Reproduced with permission of the artist Eugenie Lee.
Figure 3: Seeing is Believing, by Eugenie Lee (UNsw Galleries, Sydney, 2016). The VR experience inside the chamber, designed by Andrew Burrell. Photograph: Andrew Burrell. Reproduced with permission of the artist Eugenie Lee. 
situación inesperadamente humorística y romántica a una pareja durante un día tormentoso, el mismo quiebre podría arruinar el momento de otra persona. Como ejemplo de esto, la Cafetera para masoquistas de Jacques Carelman inevitablemente terminará quemando la mano de la persona que sirve el café. El diseño de esta cafetera desafía cualquier intento de uso normalizado. Sin embargo, esta pieza puede abrir espacios de reflexión, conversación y humor si se "usa" fuera de los límites rígidos de lo que una cafetera "debiera" hacer. Este aspecto evidencia que las experiencias estéticas son situadas, complejas y no necesariamente propiedades integradas en los artefactos diseñados (Petersen et al., 2004).

\section{CONCLUSIONES}

Atendiendo a la variedad de definiciones de lo que hace que una experiencia con productos y artefactos sea estética, este artículo ha ofrecido un marco teórico para la comprensión de las experiencias estéticas informadas por tres precedentes filosóficos principales. Primero, se basa en la definición de Dewey de experiencias estéticas, en la que la construcción de significado se desarrolla como un proceso de sucesiones rítmicas que ocurren en la vida cotidiana. Luego, este flujo rítmico de vida se analiza utilizando el modelo procesal de Gendlin, el cual conecta generativamente implicaciones y ocurrencias al tiempo que reconoce los obstáculos como una oportunidad para llevar adelante el proceso de la vida. Finalmente, se introduce el análisis de acción de Heidegger a través de la transparencia de los artefactos. Las tres teorías se abordan en términos de diferentes escenarios encarnados en los cuales podrían surgir experiencias estéticas con objetos: (1) transparencia, (2) dialogar con el artefacto, (3) diseñar obstáculos para el fluir, y (4) el quiebre. En términos de su relevancia, este marco teórico contribuye con una serie de consideraciones para ofrecer encuentros estéticos con productos y artefactos que escapan a la tendencia a identificar las experiencias estéticas como necesariamente positivas, con lo cual podríamos estar pasando por alto oportunidades para diseñar objetos que aporten a la construcción de significado. Al challenging, yet the breakdown in itself is an opportunity for observation, creative engagement, and learning (Dreyfus, 1991; Winograd \& Flores, 1986). As a broken umbrella could provide an unexpectedly humorous and romantic situation to a couple during a stormy day, the same breakdown could potentially ruin someone else's moment. As an example of this, manipulating Jacques Carelman's Coffeepot for Masochists would end up inevitably burning the hand of the server. The design of this pot defies any attempt of normalized usage. However, this piece can open up spaces for reflection, conversation, and humor if 'used' outside the rigid boundaries of what a coffee pot is supposed to do. This aspect makes evident how aesthetic experiences are situated, complex and not necessarily properties embedded in designed artifacts (Petersen et al., 2004).

\section{CONCLUSIONS}

Attending to the variety of definitions of what makes an experience aesthetic with products and artifacts, this paper has offered a theoretical framework for the understanding of aesthetic experiences informed by three main philosophical precedents. First, it is based on Dewey's definition of aesthetic experiences, in which meaning unfolds as rhythmical successions occurring in everyday life. Then, this rhythmic flow of living is discussed using Gendlin's process model, which generatively connects implications and occurrences whilst acknowledging obstacles as an opportunity of carrying forward with the process of life. Finally, Heidegger's analysis of action through the transparency of equipment was introduced. The three theories are discussed in terms of different embodied scenarios where aesthetic experiences with objects could potentially emerge: (1) transparency, (2) dialoguing with equipment, (3) design obstacles to the flow, and finally, (4) the breakdown. In terms of relevance, this theoretical framework contributes with a series of considerations for delivering aesthetic encounters with 
mismo tiempo, evita definir la estética desde el punto de vista de las cualidades, ya que con ello corremos el riesgo de limitar la riqueza y el significado de las experiencias estéticas. Este marco debe usarse como una herramienta reflexiva para pensar acerca del diseño de experiencias estéticas en términos de flujos y obstáculos, incluso considerando la importancia de desarrollar experiencias que escapen del placer directo para que surja la construcción de significado. En términos de las posibles aplicaciones futuras en el contexto de la investigación basada en la práctica, este marco podría abrir oportunidades para el análisis comparativo entre diferentes formas de abordar un desafío de diseño mediante la evaluación de diferentes dimensiones del fluir y su impacto en la recepción del usuario. Aunque es situado y abierto, el uso de obstáculos en el diseño de interacciones debe idearse detallada y concienzudamente, teniendo en cuenta aspectos éticos como el consentimiento informado y procurando evitar transgredir susceptibilidades socioculturales. products and artefacts that escape the tendency to identify aesthetic experiences as necessarily positive, as it overlooks opportunities for the design of meaningful objects. At the same time, it avoids defining aesthetics from the standpoint of qualities, which risks limiting the richness and meaningfulness of aesthetic experiences. This framework is to be used as a reflective tool to think about the design of aesthetic experiences in terms of flows and obstacles, even considering the importance of developing experiences that escape from straightforward pleasure for the emergence of meaning. In terms of possible future applications in the context of practice-based research, this framework could open up opportunities for comparative analysis between different ways of approaching a design challenge, by evaluating different flow dimensions and their impact on user reception. Although situated and open, the use of obstacles in the design of interactions should be well thought out, taking into account ethical aspects such as informed consent, and being careful to avoid offending socio-cultural susceptibilities. D 


\section{REFERENCIAS / REFERENCES}

BADER, J. D., \& LOWENTHAL, P. R. (2018). Using Visual Design to Improve the Online Learning Experience: A Synthesis of Research on Aesthetics. In I. Bouchrika, N. Harrati, \& P. $\mathrm{Vu}$, Learner Experience and Usability in Online Education (pp. 1-35). Hershey, USA: IGı Global.

BENFORD, S., GREENHALGH, C., GIANNACHI, G., WALKER, B., MARSHALL, J., \& RODDEN, T. (2012). Uncomfortable Interactions. Proceedings of the SIGCHI Conference on Human Factors in Computing Systems (May 5-10, 2012, Austin, Texas, USA), 2005-2014. Doi: $10.1145 / 2207676.2208347$

BENFORD, S., GREENHALGH, C., GIANNACHI, G., WALKER, B., MARSHALL, J., TENNENT, P., \& RODDEN, T. (2018). Discomfort-The Dark Side of Fun. In M. Blythe \& A. Monk (Eds.), Funology 2: From Usability to Enjoyment (pp. 209-224). Cham, Switzerland: Springer International.

COX, A. L., GOULD, S. J. J., CECCHINATO, M. E., IACOVIDES, I., \& RENFREE, I. (2016). Design Frictions for Mindful Interactions: The Case for Microboundaries. Proceedings of the $2016 \mathrm{CHI}$ Conference Extended Abstracts on Human Factors in Computing Systems (May 7-12, 2016, San Jose, CA, USA), 1389-1397. Doi: 10.1145/2851581.2892410

CSIKSZEnTMIhAlyı, M. (2014). Toward a Psychology of Optimal Experience. In M. Csikszentmihalyi, Flow and the Foundations of Positive Psychology: The Collected Works of Mihaly Csikszentmihalyi (pp. 209-226). Dordrecht, the Netherlands: Springer.

DALSGAARD, P. (2014). Pragmatism and Design Thinking. International Journal of Design, 8(1), 143-155.

DELOSANGELES, D. (2018). Eugenie Lee's Seeing is Believing: VR in Pain Management. Artlink Magazine, 38(4), 73.

DEWEY, J. (1934). Art as Experience. New York, USA: Minton, Balch, and Co.

DOURISH, P. (2001). Where the Action Is: The Foundations of Embodied Interaction. Cambridge, USA: MIT Press.

DREYFUS, H. L. (1991). Being-in-the-World A Commentary on Heidegger's Being in Time, Division I. Cambridge, USA: MIT Press.

FOLKMANN, M. N. (2018). Exploring Aesthetics in Design: Implications for Human-computer Interaction. Human Technology, 14(1), 6-26. Doi: 10.17011/ht/ urn.201805242750

FORLIZZI, J., \& BATTARBEE, K. (2004). Understanding Experience in Interactive Systems. Proceedings of the 5 th Conference on Designing Interactive Systems: Processes, Practices, Methods, and Techniques (August 1-4, 2004, Cambridge, USA), 261-268. Doi: $10.1145 / 1013115.1013152$
GAVER, W. W., BEAVER, J., \& BENFORD, S. (2003). Ambiguity as a Resource for Design. Proceedings of the SIGCHI Conference on Human Factors in Computing Systems (April 05-10, 2003, Ft. Lauderdale, USA), 233-240. Doi: $10.1145 / 642611.642653$

GENDLIN, E. T. (1978). Focusing. New York, USA: Bantam Books.

GENdLIN, E. T. (1981). A Process Model. New York, USA: The Focusing Institute.

GENDLIN, E. T. (2012). Implicit Precision. In z. Radman (Ed.), Knowing Without Thinking: Mind, Action, Cognition and the Phenomenon of the Background (pp. 141-166). Basingstoke, England: PalgraveMacmillan.

GIBSON, J. J. (1977). The Theory of Affordances. In R. Shaw \& J. D. Bransford (Eds.), Perceiving, Acting and Knowing: Toward an Ecological Psychology (pp. 67-82). Hillsdale, usA: Lawrence Erlbaum.

HASSENZAHL, M. (2010). Experience Design:

Technology for All the Right Reasons.

Synthesis Lectures on Human-Centered Informatics, 3(1), 1-95. Doi: 10.2200/ SOO261ED1V01Y201003 HCIOO8

HASSENZAHL, M., DIEFENBACH, S., \& GÖRITZ, A. (2010). Needs, Affect, and Interactive Products Facets of User Experience. Interacting with Computers, 22(5), 353-362. Doi: 10.1016/j. intcom.2010.04.002

HEKKERT, P. (2006). Design Aesthetics: Principles of Pleasure in Design. Psychology Science, 48(2), 157-172.

нӧӧк, к. (2018). Designing with the Body: Somaesthetic Interaction Design. Cambridge, USA: MIT Press.

HÖÖK, K., CARAMIAUX, B., ERKUT, C., FORLIZZI, J., HAJINEJAD, N., HALLER, M., ... TOBIASSON, H. (2018). Embracing First-Person Perspectives in SomaBased Design. Informatics, 5(1). Doi: 10.3390/ informatics5010008

IHDE, D. (2010). Heidegger's Technologies:

Postphenomenological Perspectives. New York, USA: Fordham University Press.

KIMBELL, L. (2011). Rethinking Design Thinking: Part I. Design and Culture, 3(3), 285-306. Doi: 10.2752 $/ 175470811 X_{13071166525216}$

LENZ, E., HASSENZAHL, M., \& DIEFENBACH, S. (2017). Aesthetic Interaction as Fit between Interaction Attributes and Experiential Cualities. New Ideas in Psychology, 47, 80-90. Doi: 10.1016/j. newideapsych.2017.03.010 
LÖWGREN, J. (2009). Toward an Articulation of Interaction Esthetics. New Review of Hypermedia and Multimedia, 15(2), 129-146. Doi: 10.1080/13614560903117822

MCCARTHY, J., \& WRIGHT, P. (2004). Technology as Experience. Cambridge, USA: MIT Press.

mCCARTHY, J., \& WRIGHT, P. (2005). Putting 'Felt-life' at the Centre of Human-computer Interaction ( $\mathrm{HCl})$. Cognition, Technology and Work, 7(4), 262-271. Doi: 10.1007/s10111005-0011-y

MERLEAU-PONTY, M. (1962). Phenomenology of Perception. London, England: Routledge.

NORMAN, D. A. (2013). The Design of Everyday Things. New York, USA: Basic Books.

NÚÑEZ-PACHECO, C., \& LOKE, L. (2014). Crafting the Body-tool: A Body-centred Perspective on Wearable Technology. Proceedings of the 2014 Conference on Designing Interactive Systems (June 21-25, 2014, Vancouver, Canada), 553-566. Doi: 10.1145/2598510.2598546

PAPPAS, I. O., SHARMA, K., MIKALEF, P., \& GIANNAKOS, M. N. (2018). Visual Aesthetics of E-Commerce Websites: An Eye-Tracking Approach. Proceedings of the 51st Hawaii International Conference on System Sciences (January 2-6, 2018, Waikoloa Village, USA).

PETERSEN, M. G., IVERSEN, O. S., KROGH, P. G., \& LUdVIGSEN, M. (2004). Aesthetic Interaction: A Pragmatist's Aesthetics of Interactive Systems. Proceedings of

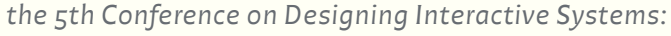
Processes, Practices, Methods, and Techniques (August 1-4, 2004, Cambridge, USA), 269-276. Doi: 10.1145/1013115.1013153

PIERCE, J., \& PAULOS, E. (2015). Making Multiple Uses of the Obscura 1 C Digital Camera: Reflecting on the Design, Production, Packaging and Distribution of a Counterfunctional Device. Proceedings of the 33 rd Annual ACM Conference on Human Factors in Computing Systems (April 18-23, 2015, Seoul, Republic of Korea), 2103-2112. Doi: $10.1145 / 2702123.2702405$

ROMdENH-ROMLUC, K. (2010). Routledge Philosophy Guidebook to Merleau-Ponty and Phenomenology of Perception. New York, USA: Routledge.

SHUSTERmAN, R. (2011). Somaesthetics: Thinking Through the Body and Designing for Interactive Experience. In $\mathrm{M}$. Soegaard \& R. F. Dam (Eds.), The Encyclopedia of HumanComputer Interaction, 2nd Ed. (pp. 1341-1375). Aarhus, Denmark: The Interaction Design Foundation.

SUTCLIFFE, A. (2009). Designing for User Engagement: Aesthetic and Attractive User Interfaces. Synthesis Lectures on Human-Centered Informatics, 2(1), 1-55. Doi: 10.2200/SOO210ED1V01Y200910 HCIOO5
SVANAS, D. (2013). Interaction Design For and with the Lived Body: Some Implications of MerleauPonty's Phenomenology. АCM Transactions on Computer-Human Interaction, 20(1), 8:1-8:30. Doi: $10.1145 / 2442106.2442114$

VERBEEK, P.-P. (2006). Materializing Morality: Design Ethics and Technological Mediation. Science, Technology, \& Human Values, 31(3), 361-380. Doi: $10.1177 / 0162243905285847$

WEISER, M. (1991). The Computer for the 21st Century. Scientific American, 265(3), 94-104. Doi: 10.1038/scientificamericanog91-94

WINOGRAD, T., \& FLORES, F. (1986). Understanding Computers and Cognition: A New Foundation for Design. New Jersey, USA: Intellect Books.

WRIGHT, P., \& MCCARTHY, J. (2008). Empathy and Experience in $\mathrm{HCl}$. Proceedings of the SICCHI Conference on Human Factors in Computing Systems (April 5-10, 2008, Florence, Italy), 637-646. Doi: 10.1145/1357054.135715

ZHU, B. T., ZHANG, Y., MA, X., \& LI, H. (2015). Bringing Chinese Aesthetics into Designing the Experience of Personal Informatics for Wellbeing. Design and Semantics of Form and Movement (DesforM 2015): Aesthetics of interaction: Dynamic, Multisensory, Wise (October 13-17, 2015, Milan, Italy), 289-298. Milan, Italy: Koninklijke Philips Electronics. 